\title{
Human serum antibody reactivity towards Paracoccidioides brasiliensis antigens treated with sodium metaperiodate
}

\author{
Reatividade de anticorpos de soros humanos a antígenos de \\ Paracoccidioides brasiliensis tratados com metaperiodato sódico
}

\begin{abstract}
Ana Paula Ferreira', Thadeu Côrrea ${ }^{1}$, Rosângela Cunha² ${ }^{1}$ Marcos José Marques ${ }^{1}$, Maria Angela Montesano ${ }^{1}$, Maria Aparecida Souza ${ }^{1}$ and Henrique Couto Teixeira ${ }^{1}$
\end{abstract}

\begin{abstract}
In this study, we evaluated the profile of anti-Paracoccidioides brasiliensis immunoglobulin isotypes in serum from patients with the acute and chronic forms of paracoccidioidomycosis, using the whole Paracoccidioides brasiliensis antigen and the antigen treated with sodium metaperiodate. All the immunoglobulin isotypes present in the serum from patients with the acute and chronic forms of paracoccidioidomycosis presented higher reactivity towards the whole antigen than to the antigen treated with metaperiodate $(P<0.05)$. The reactivity of $\operatorname{IgG}$ and $\operatorname{IgM}$ to the antigen treated with metaperiodate was greater in serum from patients with the acute form of the disease $(P<0.05)$, while IgA was more reactive in serum from patients with the chronic form $(P<0.05)$. There was greater reactivity of IgG1 and IgG2 to the whole antigen and the antigen treated with metaperiodate in the serum from patients with paracoccidioidomycosis than there was in serum from patients with other parasitic infections $(P<0.05)$. Furthermore, IgG1 from patients with the acute form recognized the $19 \mathrm{kDa}, 27 \mathrm{kDa}$ and $31 \mathrm{kDa}$ antigens in the western blot test. Thus, the results suggest that modifications to the epitopes of Paracoccidioides brasiliensis antigens may help to improve the immunodiagnosis of paracoccidioidomycosis.
\end{abstract}

Key-words: Paracoccidioidomycosis. Antigens. Metaperiodate. Diagnosis.

\section{RESUMO}

Neste trabalho, foi avaliado o perfil de isotipos de imunoglobulinas anti-Paracoccidioides brasiliensis em soros de pacientes com formas crônica e aguda de paracoccidiodomicoses usando antígeno total e tratado com meta-periodato. Todos os tipos de imunoglobulinas presentes nos soros de pacientes com formas aguda e crônica apresentaram alta reatividade ao antígeno total quando comparado ao tratado com meta-periodato $(P<0,05)$. Houve maior reatividade de IgG e IgM anti-antígeno tratado com meta-periodato em soros de pacientes com forma aguda da doença $(P<0,05)$, enquanto IgA foi mais reativa em soros da forma crônica $(P<0,05)$. Houve maior reatividade de IgG1 e IgG2 com antígeno total e tratado com meta-periodato em soros de pacientes comparados aos com outras parasitoses $(P<0,05)$. Além disso, IgG1 de pacientes com a forma aguda reconhecem antígenos de $19 \mathrm{kDa}, 27 \mathrm{kDa}$ e $31 \mathrm{kDa}$ por western blot. Assim, os resultados sugerem que alterações nos epitopos de antígenos de Paracoccidioides brasiliensis podem auxiliar no aprimoramento do imunodiagnóstico da paracoccidioidomicose.

Palavras-chaves: Paracoccidiodomicose. Antígenos. Metaperiodato. Diagnóstico.

Paracoccidioidomycosis (PCM), a granulomatous disease caused by the dimorphic fungus Paracoccidioides brasiliensis, is the most prevalent systemic mycosis in Latin America ${ }^{4}$. Symptomatic individuals show one of two main clinical forms of the disease: the acute or subacute form, which is characterized by rapid and progressive infection and largely affects the mononuclear phagocyte system; and the chronic form, which frequently shows a slow course of pulmonary disease with mucocutaneous involvement.
The criteria for laboratory diagnosis of PCM rely on positive microscopic identification of the causative agent in $\mathrm{KOH}$ preparations or biopsy specimens, as well as on its isolation in cultures $^{512}$. In addition, diagnostic methods based on serological tests have also been widely used to support identification of microscopy-positive cases ${ }^{514}$ and represent an important tool for follow-up of PCM patients ${ }^{6}$. However, serological tests normally use crude antigenic preparations of Paracoccidioides brasiliensis, which may be cross-reactive with tests for other mycotic diseases ${ }^{8}$.

\footnotetext{
1. Laboratório de Imunologia, Deptartamento de Parasitologia, Microbiologia e Imunologia, Instituto de Ciências Biológicas, Universidade Federal de Juiz de Fora, Juiz de Fora, MG. 2. Serviço de Doenças Infecciosas e Parasitárias, Hospital Universitário, Universidade Federal de Juiz de Fora, Juiz de Fora, MG.

Financial Support: CNPq, FAPEMIG and CAPES

Address to: Dra. Ana Paula Ferreira. Laboratório de Imunologia/ Dept ${ }^{\circ}$ de Parasitologia, Microbiologia e Imunologia/ICB/UFJF. 36036-900 Juiz de Fora, MG.

Telefax: 5532 2102-3214

e-mail: ana.paula@uff.edu.br

Recebido para publicação em 18/4/2008

Aceito em 29/07/2008
} 
Serum cross-reactivity of PCM with histoplasmosis and Jorge Lobo's disease has also been detected when 43-kDa glycoprotein, an exocellular antigen obtained from a liquid culture medium of Paracoccidioides brasiliensis, is used. Cross-reactivity towards gp 43 seems to be due to carbohydrate epitopes, since more than $85 \%$ of the specific reactions of gp 43 with serum antibodies from PCM patients have involved protein epitopes ${ }^{17}$.

In this study, treatment with sodium metaperiodate was used to disrupt the carbohydrate epitopes of Paracoccidioides brasiliensis filtrate antigens and generate a purified protein antigenic preparation . Whole Paracoccidioides brasiliensis soluble antigens (WAg) and sodium metaperiodate-treated WAg (MPAg) were used to evaluate the profile of serum immunoglobulin isotype (total IgG, IgM, IgA, IgG1 and IgG2) reactivity towards Paracoccidioides brasiliensis in patients with acute or chronic forms of PCM. Furthermore, we used the western blot method to investigate serum IgG1 reactivity towards fractionated Paracoccidioides brasiliensis antigens in serum from acute and chronic PCM patients.

\section{MATERIAL AND METHODS}

Patients and controls. The study was conducted on serum samples obtained from twenty-nine patients with active PCM with either the acute form $\left(n^{0}=15\right)$ or chronic form $\left(n^{0}=14\right)$ of the disease. All the patients had PCM, according to the clinical diagnosis of symptoms that indicates presence of Paracoccidioides brasiliensis infection, and according to positive cultures and immunodiffusion tests for crude Paracoccidioides brasiliensis antigens. The samples were obtained from the University Hospital, Federal University of Juiz de Fora, Minas Gerais, Brazil, with the approval of the Ethics Committee for Human Research (№ 098-22/2000). For this study, the controls comprised five normal individuals and five patients with Chagas' disease or leishmaniasis.

Paracoccidioides brasiliensis antigenic preparation. Whole Paracoccidioides brasiliensis soluble antigenic preparation (WAg) was obtained as described previously ${ }^{10}$. The isolate of Paracoccidioides brasiliensis came from an individual with the acute form of PCM and the inoculum was cultured for 15 days in Sabouraud medium. Fungal suspensions were washed (3X) in sterile saline at 3,000rpm for $5 \mathrm{~min}$. The fungal mass was resuspended in an equal volume of sterile saline containing phenylmethylsulfonyl fluoride (PMSF) $(20 \mu \mathrm{l} / \mathrm{ml})$ and then subjected to sonication (100 cycles/3 $\mathrm{min} ; 20 \mathrm{X}$ ) in an ice bath. After centrifugation at $10,000 \mathrm{rpm}$ for $40 \mathrm{~min}$, the supernatant was dialyzed against distilled water for $48 \mathrm{~h}$ and stored at $-20^{\circ} \mathrm{C}$.

Periodate oxidation. Carbohydrate groups of WAg were disrupted by treatment with sodium metaperiodate (Sigma), which yielded a purified protein antigenic preparation (MPAg). WAg was adsorbed onto flat-bottom Immunolon II microtiter plates, washed twice with $0.05 \mathrm{M}$ sodium acetate $(\mathrm{pH} 4.5)$ and treated with sodium metaperiodate $(10 \mathrm{mM}$ in the acetate buffer) for one hour in darkness at room temperature. Afterwards, the plates were washed twice with sodium acetate and the reaction was stopped by adding sodium borohydride (50mM in PBS)
(Sigma) for $30 \mathrm{~min}$ at room temperature. The plates were then washed twice with PBS.

Isotyping. Antibody isotype analyses were performed by specific ELISA to detect anti-Paracoccidioides brasiliensis reactivity, using plates adsorbed with WAg and MPAg Paracoccidioides brasiliensis antigens. Horseradish peroxidase (HRP)-conjugated, isotype-specific mouse anti-human IgG (antitotal IgG), antiIgM, anti-IgA, anti-IgG1 or anti-IgG2 (Southern Biotechnology Associates, Inc.) were used and the assays were developed by adding tetramethylbenzidine (TMB) peroxidase substrate solution (Kirkegaard \& Perry Laboratories). The reaction was stopped by adding $1 \mathrm{M} \mathrm{H}_{2} \mathrm{SO}_{4}$, and the color reaction was read at $450 \mathrm{~nm}$ in a microplate reader (Molecular Devices Corp).

Western blotting. WAg antigen was diluted in an SDS sample buffer (2\% v/v SDS, 2\% v/v 2-ME, 10\% v/v glycerol and $0.01 \%$ bromophenol blue in $0.125 \mathrm{M}$ Tris-HCl buffer, $\mathrm{pH} 6.8$ ), heated at $95^{\circ} \mathrm{C}$ for $5 \mathrm{~min}$ and analyzed by means of SDS-PAGE on $10 \%$ polyacrylamide gels. After electrophoresis, the antigenic fractions were transferred to nitrocellulose. The blots were blocked with $0.05 \%$ PBS, Tween 20 and 5\% nonfat dried milk for $30 \mathrm{~min}$. Serum samples (1:100) were added to each strip for $60 \mathrm{~min}$ at room temperature and then they were washed with blocking buffer. HRP-conjugated isotype-specific mouse anti-human anti-IgG1 $(1: 1,000)$ was added to each strip. After $60 \mathrm{~min}$, the strips were washed and the color reaction was developed with $0.06 \%$ 4-chloro-1-naphthol in tris-buffered saline (TBS) solution for $10 \mathrm{~min}$. The reaction was stopped by adding $3.3 \mu \mathrm{l}$ of $\mathrm{H}_{2} \mathrm{O}_{2}$.

Statistical analysis. The Mann-Whitney $\mathrm{U}$ test was used to analyze the positive significance $(P<0.05)$ of the immunoglobulin levels in the serum from the two groups of patients. A paired nonparametric test (Wilcoxon) was used to evaluate the differences in the patients' serum reactivity towards WAg and MPAg antigenic preparations.

\section{RESULTS}

Serum immunoglobulin isotype reactivity in paracoccidioidomycosis patients. Serum from patients with both the acute and the chronic form of PCM showed higher reactivity towards all immunoglobulin isotypes (total IgG, IgM, IgA, IgG1 and IgG2) when WAg was used than when MPAg was used $(P<0.05)$ (Figures 1 and 2). Serum samples from patients with the acute form of PCM presented higher levels of total IgG (Figure 1A) and IgM (Figure 1B) anti-Paracoccidioides brasiliensis antibodies than did serum samples from patients with the chronic form of the disease, when the MPAg was used $(P<0.05)$. On the other hand, IgA levels specific to WAg were higher in the serum from chronic PCM patients than in the serum from acute patients (Figure 1C) $(P<0.05)$.

There were no significant differences in the reactivity of serum IgG1 and IgG2 between patients with the acute and chronic forms of PCM, regardless of the antigenic preparation used (Figure 2). However, the reactivity of the IgG1 (Figure 2A) and IgG2 (Figure 2B) isotypes in patients with PCM was higher $(P<0.05)$ than 
in the healthy controls or non-PCM diseased controls (Figure 2). Serum from patients with chronic PCM showed only low levels of specific IgG3 and IgG4 when either WAg or MPAg were used (data not shown).

Serum reactivity distinguished by western blotting. Western blot analysis with Paracoccidioides brasiliensis WAg using anti-human IgG1 polyclonal antibodies showed that antigens with molecular weights of approximately $19 \mathrm{kDa}, 27 \mathrm{kDa}$ and $31 \mathrm{kDa}$ were markedly recognized by the serum immunoglobulins from patients with the acute form of PCM. In contrast, serum from both the chronic and the acute PCM patients reacted with antigens of $43 \mathrm{kDa}$ and $75 \mathrm{kDa}$ (Figure 3).

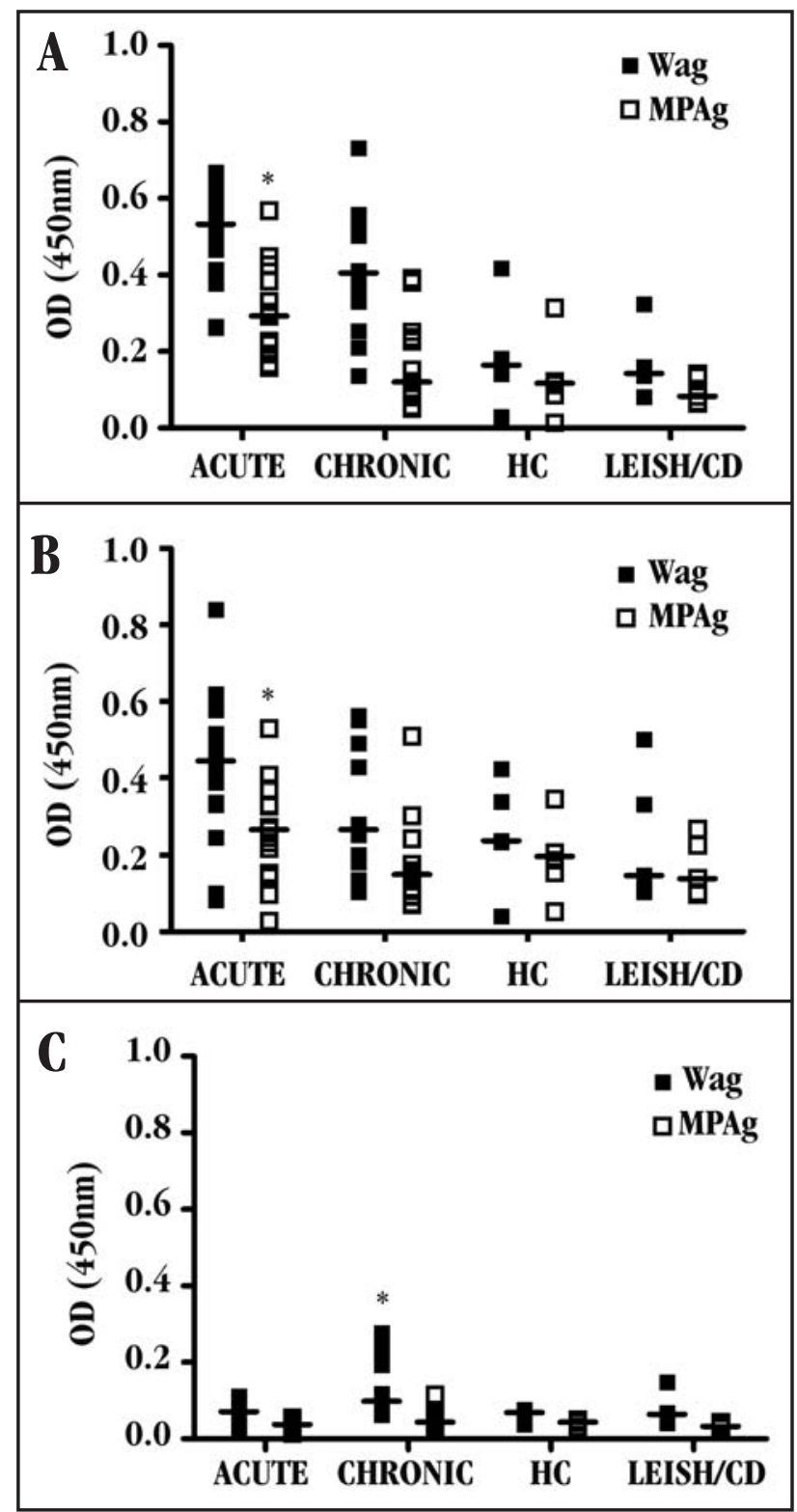

All serum samples were tested against whole (WAg) (ם) or sodium metaperiodate-treated WAg (MPAg) ( $\square$ ) of Paracoccidioides brasiliensis; horizontal line (-) represents the median values of samples detected by ELISA. The optical density (OD) was measured at $450 \mathrm{~nm}$. LEISH: Leishmaniasis, CD: Chagas disease, ${ }^{*} \mathrm{p}<0,05$ vs chronic patients (A and $\mathrm{B}),{ }^{*} \mathrm{p}<0.05$ vs acute patients (C).

Figure 1 - Reactivity of total IgG (A), IgM (B) and IgA (C) in serum from patients with acute and chronic paracoccidioidomycosis. Serum from PCM patients, bealthy controls and diseased controls were screened.

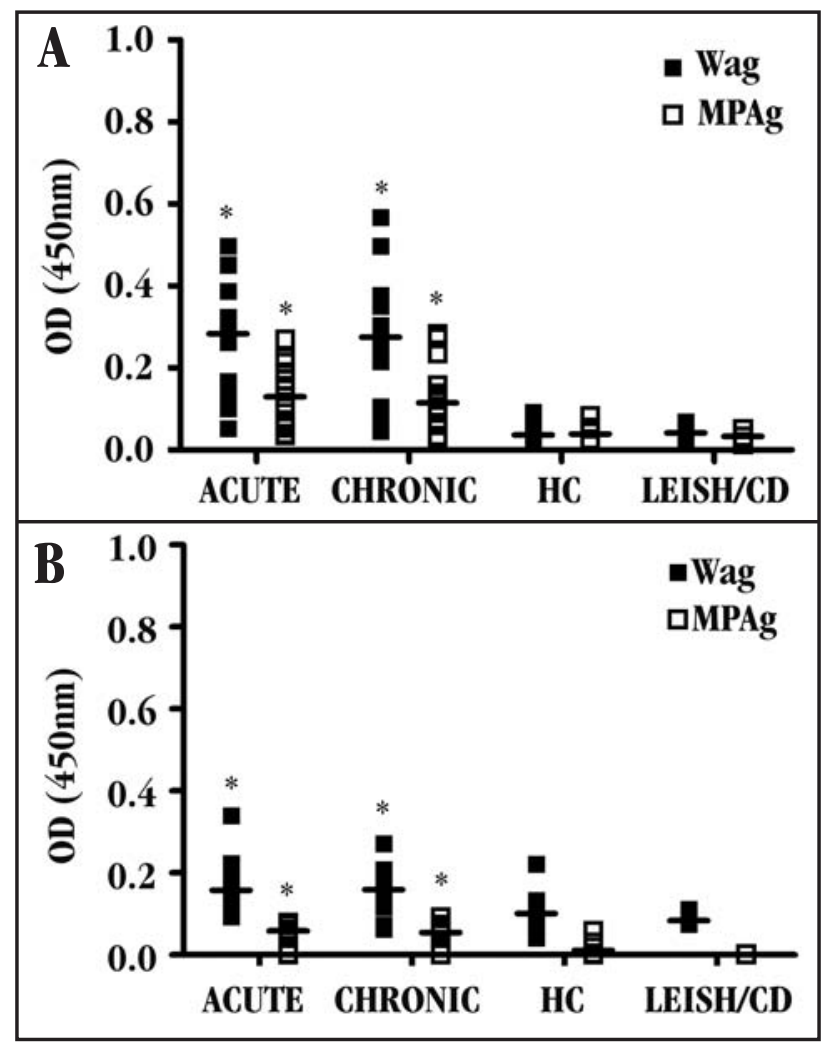

All serum samples were tested against whole antigen (WAg) (ם) or sodium metaperiodate-treated WAg (MPAg) ( $\square$ ) of Paracoccidioides brasiliensis; horizontal line (-) represents the median values of samples detected by ELISA. The optical density (OD) was measured at $450 \mathrm{~nm}$. * $\mathrm{p}<0.05 \mathrm{vs} \mathrm{HC}$ and LEISH/CD groups, LEISH: Leishmaniasis, CD: Chagas disease.

Figure 2 - Reactivity of IgG1 (A) and IgG2 (B) in the serum from PCM patients, bealthy controls and diseased controls.

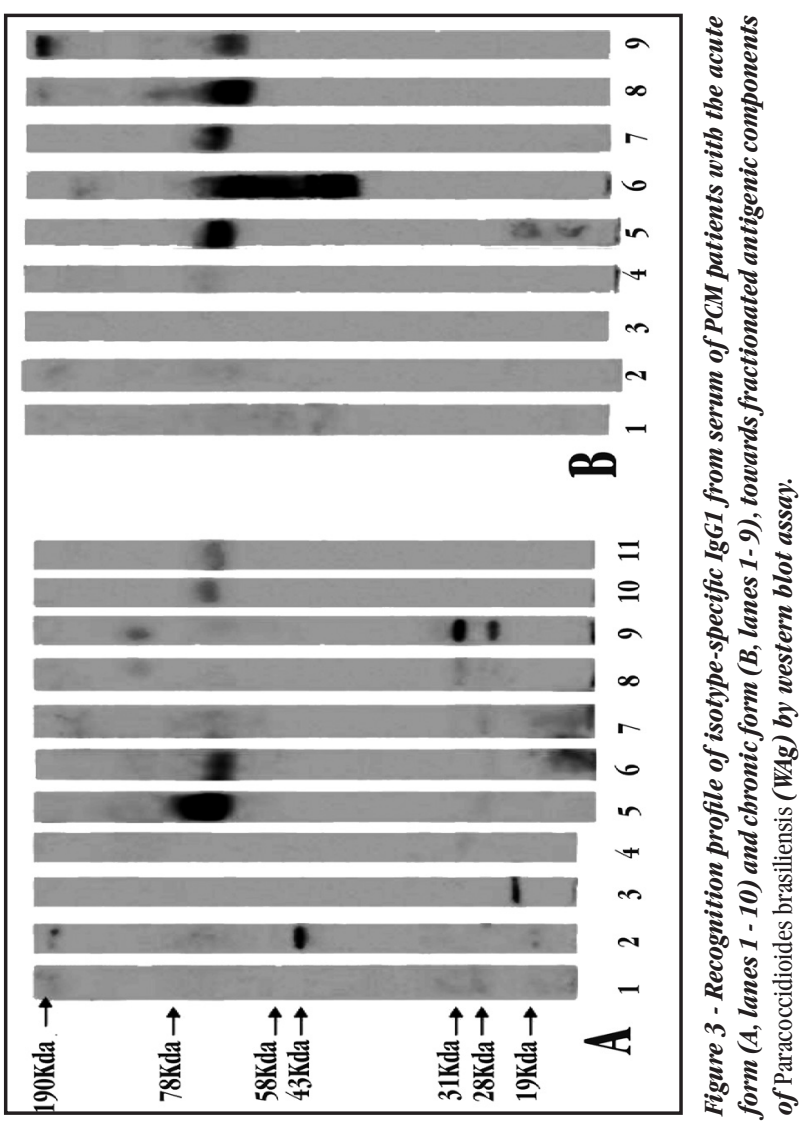




\section{DISCUSSION}

Previous studies have shown the profile of serum immunoglobulin isotypes that are reactive towards Paracoccidioides brasiliensis antigens in acute and chronic forms of PCM, using Paracoccidioides brasiliensis filtrate antigens or purified recombinant proteins ${ }^{111}$. To our knowledge, this is the first study of serum reactivity in PCM that has compared antigenic preparations obtained from Paracoccidioides brasiliensis culture filtrates that differed according to their carbohydrate content.

The use of serological tests for PCM diagnosis has been very limited, mainly due to the high frequency of cross-reactivity with other infections, such as American trypanosomiasis, leishmaniasis, histoplasmosis and Jorge Lobo's disease, among others ${ }^{18}{ }^{19}$. In order to improve the specificity, a purified $43 \mathrm{kDa}$ glycoprotein (gp43) was used in serological tests and showed high-specificity results $^{1720}$. An additional study to evaluate the reactivity of gp43 in serological tests was performed after treatment of gp 43 with metaperiodate to disrupt the carbohydrates in the molecule, and this showed a reduction in nonspecific reactivity ${ }^{18}$. Despite these findings, no study with disruption of carbohydrates from an unpurified antigenic preparation of Paracoccidioides brasiliensis has been performed. In the present study, antigens obtained from Paracoccidioides brasiliensis culture filtrate (WAg) were treated with metaperiodate to obtain a carbohydrate-modified antigenic preparation (MPAg). WAg and MPAg were used to compare differences in the serum immunoglobulin isotype profile (total IgG, IgM, IgA, IgG1 and IgG2) in groups of patients with the acute and chronic forms of PCM, by means of ELISA.

The results presented here showed that serum from patients with either acute or chronic PCM had higher levels of total IgG and IgM reactivity towards WAg than against MPAg. However, only the IgG anti-Paracoccidioides brasiliensis isotypes (and not the IgM isotypes) were significantly increased in PCM patients, in comparison with the controls. Furthermore, acute PCM patients showed increased serum IgM and IgG levels only for MPAg. Several studies have demonstrated increased IgM production in early Paracoccidioides brasiliensis infection ${ }^{2}{ }^{36}$. IgG is now seen to be higher in acute PCM patients than in chronic PCM patients and the present study is in agreement with other studies that showed that juvenile PCM patients had higher IgG anti-gp43 levels than did patients with the adult form of the mycosis ${ }^{16}$.

Analysis of IgA production also showed differences between acute and chronic PCM patients. In contrast to the higher IgG and IgM isotype reactivity in acute patients, there was higher IgA reactivity in chronic patients, which was mainly anti-WAg antigenic preparation. Together, these and previous observations ${ }^{7}$ suggest that carbohydrate epitope removal leads to decreased levels of IgA. On the other hand, higher levels of IgA reactivity towards the whole antigen could indicate lack of specificity for the reaction ${ }^{21}$. In addition, the increased levels of IgA in the chronic PCM patients might relate to chronic mucosal antigenic stimulation, which is a characteristic of the chronic form of PCM. It is very well known that chronic inflammation of the mucosa stimulates production of IgA antibodies ${ }^{1910}$. In addition, the secretory IgA in saliva from PCM patients may be indicative that it has a protective role regarding antigen neutralization on mucosal surfaces ${ }^{15}$.

Previous studies showed that IgG1 antibodies were present, frequently at high levels, in subacute and chronic PCM patients ${ }^{11}$. Using both WAg and MPAg antigenic preparations, IgG1 and IgG2 subclass levels were found to be similar in the two clinical forms. However, a significant difference in IgG1 and IgG2 levels was detected when comparing PCM patients with healthy controls and non-PCM diseased controls. Isotype-specific IgG1 western blot analysis of the reactivity towards fractionated Paracoccidioides brasiliensis antigens indicated that acute patients consistently recognize a set of antigens that are of approximately 19,27 and $31 \mathrm{kDa}$, in contrast with recognition of 43 and $75 \mathrm{kDa}$ antigens, which was common to both the acute and the chronic form. Similar findings were described by another author ${ }^{16}$, showing that a $38 \mathrm{kDa}$ antigen was recognized more frequently and intensely by the serum of acute PCM than by the serum of chronic patients. Another study showed that components of the Paracoccidioides brasiliensis with 27,34 and 43kDa were reactive towards IgG anti-Paracoccidioides brasiliensis antibodies ${ }^{13}$.

In conclusion, the present study suggests that the use of MPAg, obtained from treatment of WAg with sodium metaperiodate, could improve the serological test to distinguish between the chronic and acute forms of PCM, by testing the reactivity towards IgG and IgM. The measurement of total IgG and specific IgG1 or IgG2 was efficient in distinguishing between PCM patients and control individuals, using either WAg or MPAg. This study suggests that the detection of MPAg-specific IgG-antibodies reacting with low molecular weight antigens may be applied to the development of a better method for immunodiagnosis of paracoccidioidomycosis.

\section{ACKNOWLEDGEMENTS}

We thank Daniel Stockdell for language assistance.

\section{REFERENCES}

1. Baida H, Bicelli PJ, Juvenale M, Del Negro GM, Mendes-Giannini MJ, Duarte AJ, Benard G. Differential antibody isotype expression to the major Paracoccidioides brasiliensis antigen in juvenile and adult form paracoccidioidomycosis. Microbes and Infection 1:273-278, 1999.

2. Bernard G, Mendes-Gianini MJS, Juvenale M, Miranda ET, Duarte AJS. Immunosuppression in Paracoccidioidomycosis: T cell Hyporesponsiveness to two Paracoccidioides brasiliensis glycoproteins that elicit strong humoral immune response. The Journal Infectious Diseases 175:1263-1267, 1997.

3. Biagioni L, Souza MJ, Chamma LG, Mendes RP, Marques AS, Mota NGS, Franco M. Serological of Paracoccidioidomycosis. II - Correlation between class-specific antibodies and clinical forms of the disease. Transactions of the Royal Society of Tropical Medicine Hygiene 78: 617-621, 1984.

4. Botteon FA, Camargo ZP, Bernard G, Coelho RF, Chamone DA, Itano EN. Paracoccidioides brasiliensis - reactive antibodies in Brazilian blood donors. Medical Mycology 40:387-391, 2002.

5. Brummer E, Castaneda E, Restrepo A. Paracoccidioidomycosis: in the update. Clinical Microbiology Review 6:89-117, 1993.

6. Bueno JP, Mendes-Giannini MJ, Del Negro GM, Assis CM, Takiguti CK, ShikanaiYasuda MA. IgG, IgM and IgA antibody response for the diagnosis and follow-up of paracoccidioidomycosis: comparison of counterimmunoelectrophoresis and complement fixation. The Journal Medical Veterinary Mycology 35:213-217, 1997. 
7. Chen YL, Ben KL, Cao XM. The terminal monosaccharide of antigenic determinant is involved in the binding of human sperm to specific monoclonal IgA antibody. Shi Yan Sheng Wu Xue Bao 29:101-107, 1996.

8. Del Negro GM, Garcia NM, Rodrigues EG, Cano ML, Aguiar MS, Lirio VdS, Lacaz CS. The sensitivity, specificity and efficiency values of some serological tests used in the diagnosis of paracoccidioidomycosis. Revista do Instituto de Medicina Tropical de São Paulo 33:277-280, 1991.

9. Fayette J, Dubois B, Vandenabeele S, Bridon JM, Vanbervliet B, Durant I, Banchereau J, Caux C, Briere F. Human dentritic cells skew isotype switching of CD-40-activated naive B cells towards IgA1 and IgA2. The Journal Experimental Medicine 185:1909-1918, 1997.

10. Franco M, Bagagli E, Cunha M, Chamma LG, Fecchio D. Paracoccidioides brasiliensis antigen batches from the same isolate show immunological and biochemical differences. Mycopathology 135:13-19, 1996.

11. Juvenale M, Del Negro GMB, Duarte AJS, Benard G. Antibody isotypes to a Paracoccidioides brasiliensis somatic antigen in sub-acute and chronic form paracoccidioidomycosis. The Journal Medical Microbiology 50:127-134, 2001.

12. Lacaz CS, Porto E, Martins JEC. Paracoccidioidomicose. In: Lacaz CS (ed) Micologia Médica, $8^{\text {th }}$ edição, Sarvier Editora, São Paulo, p. 248-261, 1991.

13. Martins R, Marquesa S, Alves M, Fecchio D, Franco MF. Serological follow-up of patients with itraconazole using Dot-blot, ELISA and e Western-blot. Revista do Instituto de Medicina Tropical de São Paulo 39:261-269, 1997.

14. Mendes-Giannini MJ, Del Negro GB, Siqueira AM. Serodiagnosis. In: Franco MI, Lacaz CS, Restrepo A, Del Negro GB (eds) Paracoccidioidomycosis, CRC Press, Boca Raton, p. 345-363, 1994.
15. Miura CS, Estevão D, Lopes JD, Itano EN. Levels of specific antigen (gp43), specific antibody, and antigen-antibody complexes in saliva and serum of paracoccidioidomycosis patients. Medical Mycology 39: 423-428, 2001.

16. Panunto-Castelo A, Freitas-da-Silva G, Bragheto IC, Nartinez R, Roque-Barreira MC. Paracoccidioides brasiliensis exoantigens: recognition by $\operatorname{IgG}$ from patients with different clinical forms of paracoccidioidomycosis. Microbes and Infection 5:1205-1211, 2003.

17. Puccia R, Schenkman S, Gorin PA, Travassos LR. Exocellular components of Paracoccidioides brasiliensis identification of a specific antigen. Journal Infection and Immunity 53:199-206, 1986.

18. Puccia R, Travassos LR. 43-kilodalton glycoprotein from Paracoccidioides brasiliensis: immunochemical reactions with sera from patients with paracoccidioidomycosis, histoplasmosis, or Jorge Lobo's disease. Journal Clinical Microbiology 29:1610-1615, 1991.

19. Suzuki E, Toledo MS, Takahashi HK, Straus AH. A monoclonal antibody direct to terminal residue of B-galactofuranose of a glycolipid antigen isolated from Paracoccidioides brasiliensis: cross-reactivity with Leishmania major and Trypanosoma cruzi. Glicobiology 7:463-468, 1997.

20. Taborda CP, Camargo, ZP. Diagnosis of paracoccidioidomycosis by dot immnobindig assay for antibody detection using the purified and specific antigen GP43. Journal Clinical Microbiology 32:554-556, 1994.

21. Yokota S, Amano K, Hayashi S, Kubota T, Fujii N, Yokochi T. Human antibody response to Helicobacter pylori lipopolysaccharide: presence of an immunodominant epitope in the polysaccharide chain of lipopolysaccharide. Journal Infection and Immunity 66:3006-3011, 1998. 